\title{
木質バイオマスの二段階燃焼法に関する研究
}

\author{
阿部 文明"1，中原 真也 ${ }^{* 1}$ ，徳永 賢一 ${ }^{* 2}$
}

\section{Study on a two-stage combustion method of woody biomass}

\author{
Fumiaki ABE $^{* 1}$, Masaya NAKAHARA ${ }^{* 1}$ and Kenichi TOKUNAGA ${ }^{* 2}$ \\ ${ }^{* 1}$ Ehime Univ. Dept. of Mechanical Engineering \\ 3 Bunkyo-cho, Matsuyama-shi, Ehime 790-8577, Japan \\ ${ }^{* 2}$ Ehime Univ. Faculty of Engineering \\ 3 Bunkyo-cho, Matsuyama-shi, Ehime 790-8577, Japan
}

Received 16 June 2014

\begin{abstract}
The purpose of this study is to establish a two-stage combustion method, which has advantages of a wide range of combustion temperature and high controllability compared to the conventional methods, from the standpoint of promoting the use of woody biomass as solid fuel and the effective utilization of unused wood materials. In this method, we use a vertical grate-type combustor, into which chipped woody biomass is loaded as a batch. The wood chips are burned at a low air ratio of 0.3 to 0.5 from the top to the bottom of a fuel layer, which is opposite to the direction of supplied air flow. The two-stage combustion method can be achieved through the way described above. Under the new method, wood chip combustion can be divided into two stages, namely, pyrolytic combustion process (generation of carbides) and surface combustion process (combustion of carbides). In this paper, the combustion of wood chips with different moisture contents (11, 20, 35\%) was investigated, and the effects of the amount of air and moisture contents on the burning characteristics were discussed. The result clarified the mechanisms of combustion under the new method. In addition, we confirmed that combustion temperature and burning rate could be controlled by simply changing the amount of air. The temperature could be changed in the range of about 800 to $1300 \mathrm{~K}$ in the pyrolytic combustion process and about 800 to $1500 \mathrm{~K}$ in the surface combustion process.
\end{abstract}

Key words : Solid combustion, Woody biomass, Combustion method, Two-stage combustion

\section{1. 緒言}

周知のとおり温室効果ガスによる環境問題や東京電力・福島第一原子力発電所の事故を契機として，太陽光， 風力, バイオマス等の再生可能エネルギーが注目されている(新エネルギー・産業技術総合開発機構, 2014). こ れらの中でも森林が国土面積の $2 / 3$ を占めるわが国では，地域産業の創出と自立・分散型エネルギー資源として 木質バイオマスへの期待が高く, 液体や気体燃料化の研究・開発や現時点で実用化段階にある固体燃料による直 接燃焼方式での利用が進められている(永橋他，2009). しかしながら，木質バイオマスは「燃えやすく，熱を伝 えにくい」ために燃焼形態が複雑で(日本エネルギー学会, 2009), 燃料性状によって燃焼特性が異なり, 有効熱 量に大きな差異がみられること, 従来の燃焼技術では燃焼温度の範囲が狭く, 低温燃焼や燃焼の制御が難しいこ とから，固体然料化による利用拡大には多くの困難が予想される.

そこで本研究は，有害物を含んだ災害廃棄物の有効利用も視野に入れた木質バイオマスの燃料化を推進する観 点から, 著者らが考案した木質バイオマスの燃焼を分解燃焼過程と表面燃焼過程とに分離して連続的に二段階で 行い，空気（酸素）量を変える簡便な方法によって燃焼温度，燃焼速度を広範囲で制御可能な二段階燃焼法を確

No. 14-00321 [DOI: 10.1299/transjsme.2014tep0367]

*1 正員, 愛媛大学大学院理工学研究科（干790-8577 愛媛県松山市文京町 3)

*2 正員, 愛媛大学 工学部

E-mail of corresponding author: abe.fumiaki.mj@ehime-u.ac.jp 
立することを目的とした．なお，提案する燃焼法は，(1)縦型の火格子燃焼器を使用する (2)木質バイオマス燃料は チップ化してバッチ方式で用いる (3)燃焼用空気は下部から供給し, 燃料は上部から下方に向けて燃焼させる (4) 供給空気量は理論空気量よりも遥かに少なく(空気比 $\Lambda_{P}=0.3 \sim 0.5$ 程度) する. これらの手法により実現できる.

そこで本報では，二段階燃焼法の確立と有用性を確認するために，小型燃焼器を使用し，絶乾嵩密度が同一で 含水率が異なる 3 種類（ $Z=11 ， 20,35 \%)$ の木質チップを用いて燃焼実験を行い，この燃焼法の基礎燃焼特性と 燃焼のメカニズムを実験的に明らかにする.

\section{記号}

$A$ : 火格子面積 $\mathrm{m}^{2}$

$G$ : 燃焼率 $\mathrm{kg} /\left(\mathrm{m}^{2} \cdot \mathrm{s}\right)$

$m:$ 燃焼量 $\mathrm{kg}$

$T:$ 温度 $\mathrm{K}$

$t:$ 時間 $\mathrm{S}$

$U:$ 火移り速度（着火点（面）の移動速度） $\mathrm{mm} / \mathrm{s}$

$V_{a}:$ 空気量 $\mathrm{m}^{3} / \mathrm{s}$

$Z:$ 含水率（=水分の質量 / 木質チップの湿質量） \%

$\delta:$ 乾留層厚さ（酸化層により加熱された燃料層厚さ） $\mathrm{mm}$

$\zeta$ : 炭化物生成率（=表面燃焼開始時の総炭化物質量 /木質チップ総充填絶乾質量）％

\section{添字}

$P:$ 分解燃焼過程

$T:$ 表面燃焼過程

\section{2. 実験装置および方法}

\section{$2 \cdot 1$ 実験装置}

実験装置の概要を図 1 に示す. 装置は燃焼器, 空気供給部, 各種計測器から構成される. 燃焼器は内径 $100 \mathrm{~mm}$, 厚さ $4.5 \mathrm{~mm}$, 高さ $770 \mathrm{~mm}$ のセラミック製で, 外気の影響を避ける観点から, 燃焼器上端には直径 $25 \mathrm{~mm}$ の排気 口を持つアルミニウム製の蓋を設置した，火格子は燃焼器と同面積の銅製で，火格子開口比は約 $38 \%$ \%ある.

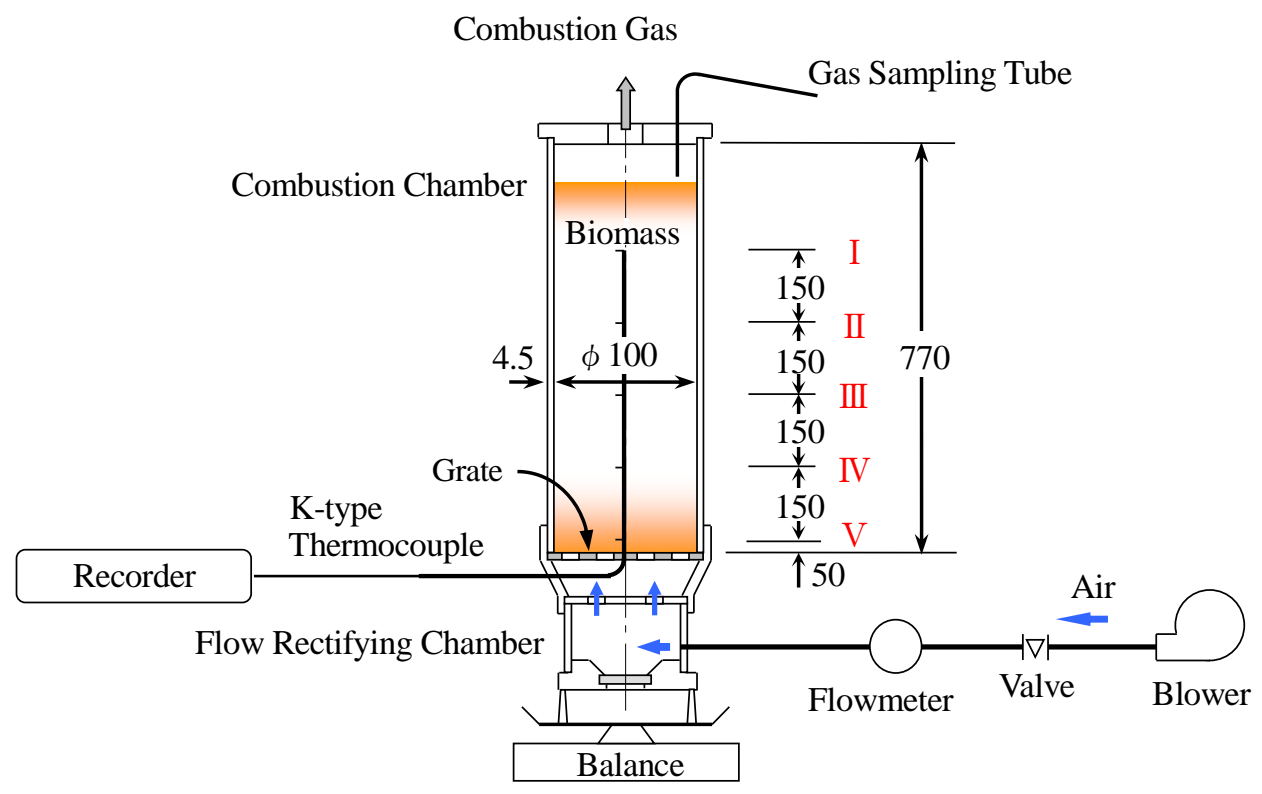

Fig. 1 Experimental apparatus 
燃焼用空気の供給には送風機を用い，流量調節弁により所定の空気量 $V_{a}$ に調節した後，燃焼室下方の整流室と 火格子を経て燃焼室にほぼ一様に供給する. さらに, 上述の燃焼器を透明な石英ガラス製燃焼器（内径 $64 \mathrm{~mm}$, 肉厚 $2.5 \mathrm{~mm}$, 高さ $200 \mathrm{~mm}$ ）に交換することで，デジタルカメラにより燃焼の可視化実験ができる．また，燃焼 器は電子天科（秤量 $15 \mathrm{~kg}$ ，分解能 $1 \mathrm{~g}$ ）上に設置する.

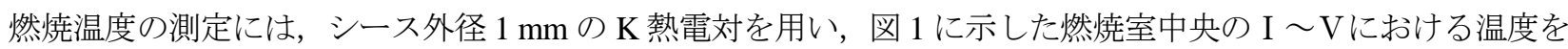
レコーダに収録する.

木質チップ燃料には，製材所で発生したヒノキ端材をチップ化し，粗大なものは目視により，また微細なもの は 5 メッシュの節を用いて取り除き, 絶乾嵩密度が $180 \mathrm{~kg} / \mathrm{m}^{3}$ 程度に揃えて使用する, さらに実験では, 選別後 の木質チップを自然乾燥により所定の含水率 $Z(=11,20 ， 35 \%)$ に調節して用いる.

\section{$2 \cdot 2$ 実験方法}

実験は，燃焼室上部の蓋を取り外し，木質チップ燃料を燃焼室容積の約 $90 \%$ まで充填する.ここで, 総充填質 量は含水率 $Z$ によって異なり，Z=11\%で $1050 \mathrm{~g}, Z=20 \%$ で $1100 \mathrm{~g}, Z=35 \%$ で $1330 \mathrm{~g}$ 程度である. さらに, 燃 料層の上層には少量の着火補助材（絶乾木材チップ $30 \mathrm{~g}$, 総充填量の $0.2 \%$ 程度）を均等に配置する. 次いで, 所定の空気を供給し，着火補助材に点火して開始する．なお，各種測定は，着火補助材の影響を避ける観点から 燃焼量が定常になるのを待って始める.

本研究では, 分解および表面燃焼過程における最高温度を分解燃焼温度 $T_{P}$ ならびに表面燃焼温度 $T_{S}$ と定義す る. また, 燃焼率 $G$ は, 燃焼室下部に設置した電子天秤により燃焼量 $m$ とその所要時間 $t$ を計測し, 次式により 算出する.

$$
G=\frac{m}{A \cdot t}
$$

次に，式（2）に一般的な木質バイオマスの組成(右田他，1971)を基にした完全燃焼時の化学反応式を示す.

$$
\mathrm{C}_{42} \mathrm{H}_{60} \mathrm{O}_{28}+43 \mathrm{O}_{2}+162 \mathrm{~N}_{2} \rightarrow 30 \mathrm{H}_{2} \mathrm{O}+42 \mathrm{CO}_{2}+162 \mathrm{~N}_{2}
$$

式 (2) より, 木質バイオマス $1 \mathrm{~kg}$ を完全燃焼させるために必要な酸素量は $43 \mathrm{~mol}$, 必要空気量は約 $4.6 \mathrm{~m}^{3} \mathrm{~N}$ とな る.これより, 本研究では, 単位時間当たりの燃焼量 $(m / t)$ が完全燃焼するのに必要な空気量を理論空気量 $V_{a 0}$ とし, 供給空気量 $V_{a}$ との比を空気比 $\Lambda\left(=V_{a} / V_{a 0}\right)$ と定義する.

また，火移り速度 $U_{P}$ の測定には熱電対 IIおよびIVを用い， $U_{P}$ は， $300 \mathrm{~mm}$ の距離を着火点が移動（図 2 の $\mathrm{F}_{\text {II }}$ から $\mathrm{F}_{\mathrm{IV}}$ まで) 寸る時間 $t$ で除して求める. なお，着火点は，木材（針葉樹）の着火温度の $493 \mathrm{~K}$ (日本エネルギー 学会, 2009)とした.

木質チップの含水率 $Z$ には湿量基準を用い，木質ペレット品質規格(日本木質ペレット協会，2011)に則して実 験毎に測定した. なお，嵩密度の測定は木質チップの選別毎に行い，試料は $378 \pm 2 \mathrm{~K}$ の恒温炉中で絶乾状態にし た後, シリカゲル乾燥剤を入れたデシケータ中で室温まで放冷させてから上述の品質規格に則して計測した.

\section{3. 実験結果および考察}

\section{$3 \cdot 1$ 燃焼形態の概観}

図 2 および図 3 に, セラミック製燃焼器を用いて（以下，表記のない場合はセラミック製燃焼器を使用），本燃 焼法により $Z=20 \%$ の木質チップを $V_{a}=1.76 \times 10^{-4} \mathrm{~m}^{3} / \mathrm{s}$ の条件で然焼させた結果の一例を示す. 図 2 には, 熱電対 II 〜Vの位置における温度変化の様子, 図 3 には, 木質チップの初期の充填量 $m_{0}$ に対する質量減少比を実験開始 からの時系列で示している.

図 2 より，木質チップの酸化層（E域）が，上部から下方に向かって約 $8 \times 10^{-2} \mathrm{~mm} / \mathrm{s}$ の火移り速度 $U_{P}$ (着火点 $\mathrm{F}_{\mathrm{II}}$ から $\mathrm{F}_{\mathrm{V}}$ の方向への移動速度）で移動（A 域）した後，火格子上で維持された（B， $\mathrm{C}$ 域）ことを確認できる. 
さらに図 2 のIIIの温度履歴より, 酸化層からの加熱が開始されると木質チップの温度 $T$ が上昇を始め（D 域）, 着火点 $\mathrm{F}_{\mathrm{II}}$ に到達して着火すると, $T$ が急上昇して燃焼が保持される. また燃焼の終了とともに $T$ は高温の燃焼力゙ スの影響を受けながら緩やかに下降する. A 域では，この一連の酸化層が前方に乾留層を形成しながら移動する 燃焼形態が上部から下方に順々に行われることがわかる．このことから， $\mathrm{A}$ 域での乾留層厚さ $\delta_{p}$ および酸化層 厚さは，Dおよび $\mathrm{E}$ 域の所要時間を計測して $U_{P}$ を乗じることでそれぞれ求めることができる.

さらに図 3 より，A および $\mathrm{B}$ 域と $\mathrm{C}$ 域では燃焼量に大きな差異がみられること， C 域の燃焼が初期充填量の 約 $16 \%$ の量によって開始され, なおかつ前燃焼過程から連続して保持されたことがわかる.この約 $16 \%$ 量は, 一般的な炭窯製炭（ $Z=35 \%$ ，炭化温度 $973 \mathrm{~K} ）$ における黒炭収量 $18 \%$ (右田他，1968)や，不活性ガス（ $\mathrm{N}_{2} ）$ 気 流中でのカラマツの急速熱分解 $(Z=17 \%$, 加熱速度 $4.2 \mathrm{~K} / \mathrm{s}$, 加熱温度 $923 \mathrm{~K})$ における炭化物残渣量約 $15 \%$ (日 本エネルギー学会, 2009) とほぼ同等である。このことから，A 域では木質チップの主に分解燃焼によって燃焼が 維持され， $\mathrm{C}$ 域では前過程で生成・蓄積した炭化物の表面燃焼によって燃焼が維持されたことが考察できる.

なお，分解燃焼が火格子に到達した直後には，ごく短時間の分解および表面燃焼が同時進行する複合燃焼状態 （図 2, B 域の約 $885 \mathrm{~K}$ から $1120 \mathrm{~K}$ に急速に昇温した時刻から C 域開始時刻までの領域）が発生し，外観上も分 解燃焼時と異なる大量の発煙が観察される. しかしながら, 本燃焼法のような低空気比燃焼の場合には, 図 2 と 図 3 が示すとおりほぼ分解然焼として取り扱うことができる.また, 図 2 および図 3 における B 域の開始時刻に は，急激な温度上昇と大量の発煙が始まるおおよその位置を示す， C 域では，燃焼率の違いを利用して燃焼量 $1 \mathrm{~g}$

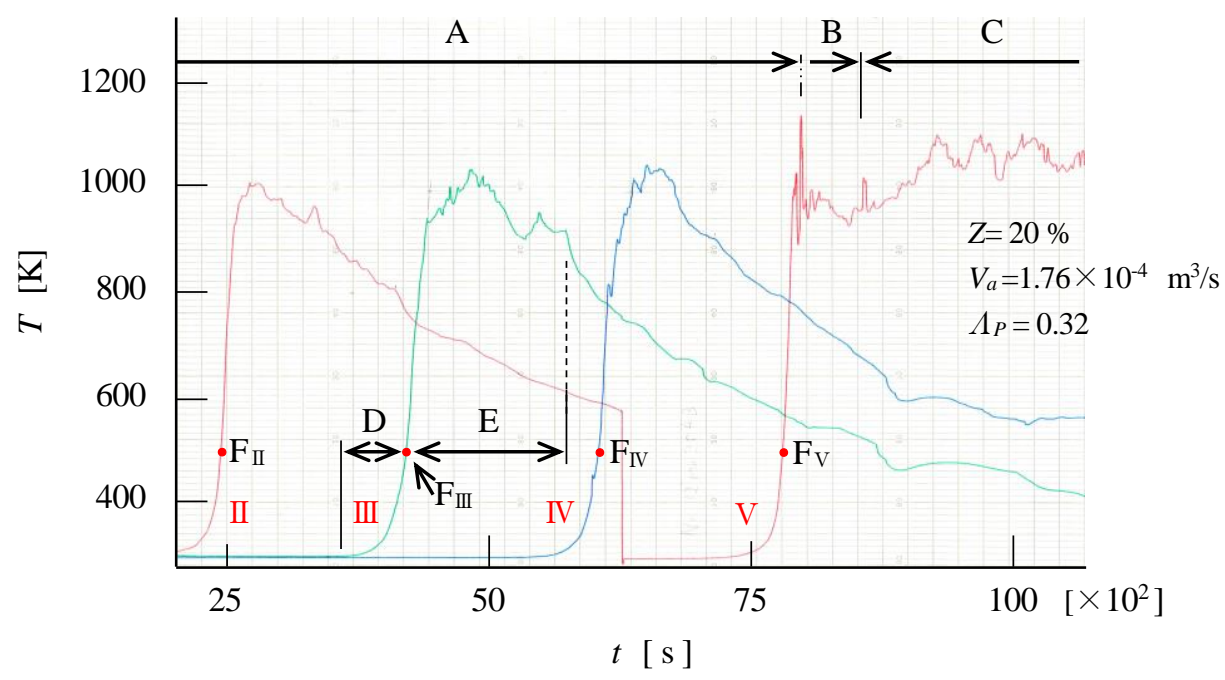

Fig. 2 Temperature history inside the combustion chamber

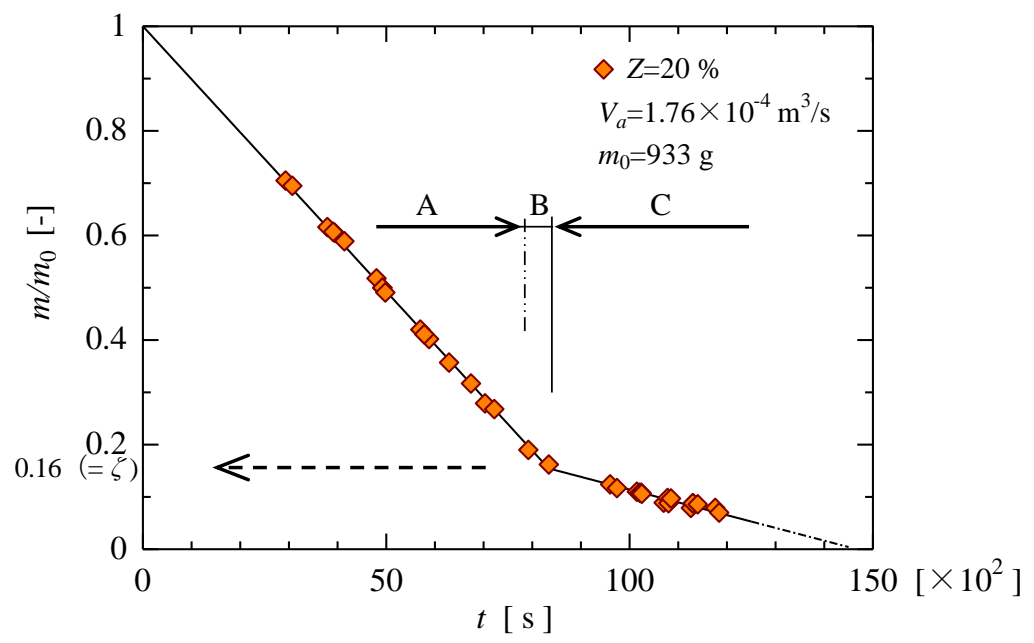

Fig. 3 Relationship between $m / m_{0}$ and $t$ 
当たりの所要時間を $\mathrm{B}$ 域から連続的に測定し, 図 3 のように $m / m_{0}$ の勾配が変化したときの時刻を $\mathrm{C}$ 域（表面燃 焼）の開始時刻とした。 さらに表面燃焼開始時の質量を分解燃焼過程で生成された総炭化物質量とする.

これらの結果から，本燃焼法では，木質チップの燃焼が炭化物を生成しながらの分解燃焼過程（図 2 の A お び B 域）と炭化物の燃焼の表面燃焼過程（図 2 の 域）との二段階で行われたことがわかる．また，炭化物の発 熱量 $34 \mathrm{MJ} / \mathrm{kg}$ (農林省林業試験場，1973)を用いた概算では，全有効熱量のうちの $60 \%$ 余りが分解燃焼過程で発生 し，残りが表面燃焼過程で生じたと推測できる．以後の議論では，本燃焼法による一段階目の燃焼を分解燃焼過 程と二段階目の燃焼を表面燃焼過程と呼ぶ.

\section{$3 \cdot 2$ 分解燃焼過程の燃焼特性}

図 4 および図 5 に，含水率が異なる $(Z=11,20,35 \%)$ 場合の分解燃焼温度 $T_{P}$ および分解燃焼過程での燃焼 率 $G_{P}$ を空気量 $V_{a}$ に対して示寸.

図 4 より， $V_{a}$ の増加とともに $T_{P}$ が上昇することがわかる. また, 本実験範囲では, $V_{a}$ を変えると $T_{P}$ が約 $900 \sim$ $1300 \mathrm{~K}$ の範囲で変化し，さらに $V_{a}<$ 約 $2.5 \times 10^{-4} \mathrm{~m}^{3} / \mathrm{s}$ では $Z$ が異なる場合でも同一空気量ではほぼ同等の $T_{P}$ にな ることが確認できる. 一方, $Z=35 \% の V_{a}>$ 約 $3 \times 10^{-4} \mathrm{~m}^{3} / \mathrm{s}$ において $T_{P}$ の急激な上昇と高温化がみられる.この 原因として, 炭化物温度が炭化物の着火温度よりも高く, さらに含水率の上昇による燃焼率の低下で空気比が上 昇し，生成後の炭化物が表面燃焼を起こしたためと推測できる.

図 5 より，いずれの含水率においても $V_{a}$ の増加とともに $G_{P}$ が増加することを確認できる. さらに, $Z=11$ と $20 \% の G_{P}$ は同等で, $Z=20 \%$ には含水率の増加による有効発熱量の低下の影響がみられない. 一方， $Z=35 \% の$ 場合には $G_{P}$ が低くなり， $V_{a}$ への依存性が小さくなることがわかる. また，本実験範囲での $G_{P}$ の值は, $4 \times 10^{-3}<$ $G_{P}<37 \times 10^{-3} \mathrm{~kg} /\left(\mathrm{m}^{2} \cdot \mathrm{s}\right)$ 程度であり, 従来の火格子燃焼での $G_{P}$ の值 $\left(40 \times 10^{-3} \sim 83 \times 10^{-3} \mathrm{~kg} /\left(\mathrm{m}^{2} \cdot \mathrm{s}\right)\right.$ ) (日本機械学 会，2002)に比べて小さい．しかしながら，本方式では，極めて低い燃焼率からの燃焼維持が可能な特徵を有する ことが期待できる.

以上の結果を詳しく検討するために, 図 6 から図 8 に, 分解燃焼過程での乾留層厚さ $\delta_{P}$ ならびに火移り速度 $U_{P}$, 炭化物生成率 $\zeta$ を分解然焼温度 $T_{P}$ に対して各々示寸.

図 6 より, いずれの含水率においても $T_{P}$ の上昇とともに $\delta_{P}$ は減少し, 徐々に依存性が小さくなる傾向が認め られる，さらに，同一燃焼温度における $\delta_{P}$ の值は $Z$ が増加すると一旦増大し，再び減少する．なお，本燃燒過 程の乾留層は，酸化層からの熱伝導と放射伝熱による加熱で形成される，一方，燃焼用空気の対流伝熱と水分の 蒸発（吸熱）は乾留層形成のための伝熱量を減少させる.さらに木質チップの熱伝導率は，杉の物性值(日本機械 学会, 2009)を参考にすれば本含水率域では $Z$ にほぼ比例すると推定される. これらのことから, 図 6 での $T_{P}$ の 上昇とともに $\delta_{P}$ が減少する原因としては，燃焼用空気による対流伝熱の影響と考えられる．また，図 6 での同 一燃燒温度における $\delta_{P}$ の差違は，熱伝導率の変化による伝熱量および水分の蒸発による影響が考えられる．し かしながら, 後者の原因に関しては, 実験結果が乏しいために今後さらに検討を要す.

図 7 より,いずれの含水率においても $T_{P}$ の増加とともに $U_{P}$ が増加することがわかる.また, $U_{P}$ の值は, $Z=11 \%$ に比べて $20 \%$ の場合にはほぼ同等で，35\%の場合には低く， $T_{P}$ の上昇とともにその差が拡大寸る. このことお よび図 5 と図 6 から， $\delta_{P}$ および $Z$ が $T_{P}$ とともに $U_{P}$ に影響を及ぼす重要な因子であることがわかる．さらに， 層状の酸化層がほぼ定常的に進行する本燃焼過程では $U_{P}$ が $G_{P}$ を決定づける.

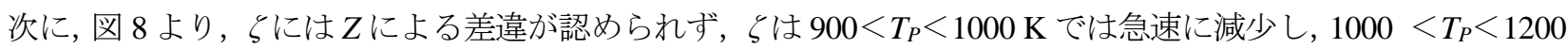
$\mathrm{K}$ ではほぼ一定となる.この傾向は, 不活性ガス $\left(\mathrm{N}_{2}\right)$ 中でのナラ材の炭化実験の結果(福山, 里中, 1954)や,

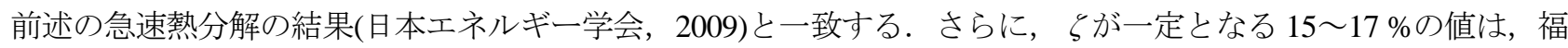
山らの木炭収量（炭化物生成率）の約 $25 \%$ よも低く, 加熱速度が $4.2 \sim 13.3 \mathrm{~K} / \mathrm{s}$, 加熱温度 $923 \mathrm{~K}$ での急速熱 分解における炭化物残渣量（炭化物生成率）18～14\%とほぼ同等である. これらのことから，本燃焼過程が木質 バイオマスの炭化と同様の熱分解支配の燃焼によって維持され，炭化物が生成されたことがわかる，なお，本実 験は, 空気比 $\Lambda_{P}=0.3 \sim 0.5$ 程度の制限空気中における炭化であり, 昇温（加熱）速度ならびに燃焼温度は供給空 気量 $V_{a}$ および含水率 $Z$ によって变化する. そのため上述の $\zeta$ の值は, 分解燃焼過程の燃焼を熱分解支配の程度で 評価したものである.

また, $Z=35 \%, T_{P}>1230 \mathrm{~K}$ での $\zeta$ の減少は, 上述の福山らの傾向とは異なり, 図 4 で見られる $Z=35 \% の V_{a}$ 
が大きい領域での高温化域と一致する。このことから，図 4 で観測された $T_{P}$ の急激な上昇と高温化は生成された 炭化物が表面燃焼を起こしたことが主な原因と考えられる.

以上の結果から，本燃焼過程が木質チップの概祮分解燃焼によって維持されたことがわかる．さらに， $V_{a}$ の調 節によって広範囲で $T_{P}$ および $G_{P}$ の制御が可能で, $T_{P}=900 \mathrm{~K}$ 程度からの低温燃焼と, $G_{P}=5 \times 10^{-3} \mathrm{~kg} /\left(\mathrm{m}^{2} \cdot \mathrm{s}\right)$ 程度 からの低燃焼率でも安定した燃焼が維持できる，従来の燃焼技術にはない特徴を確認できる.

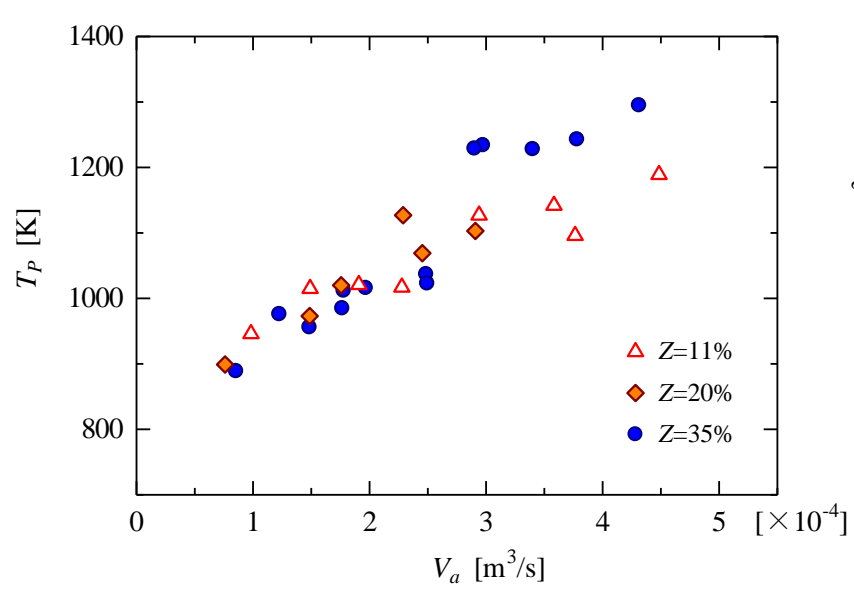

Fig. 4 Relationship between $T_{P}$ and $V_{a}$

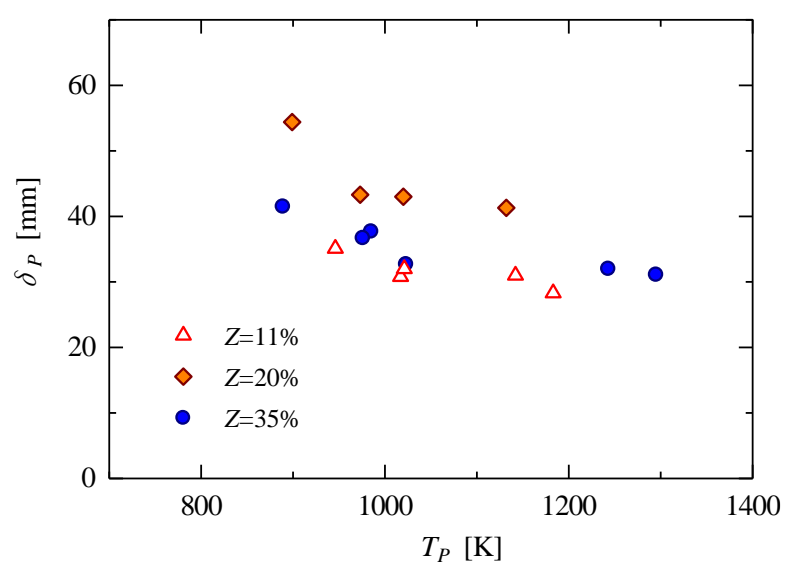

Fig. 6 Relationship between $\delta_{P}$ and $T_{p}$

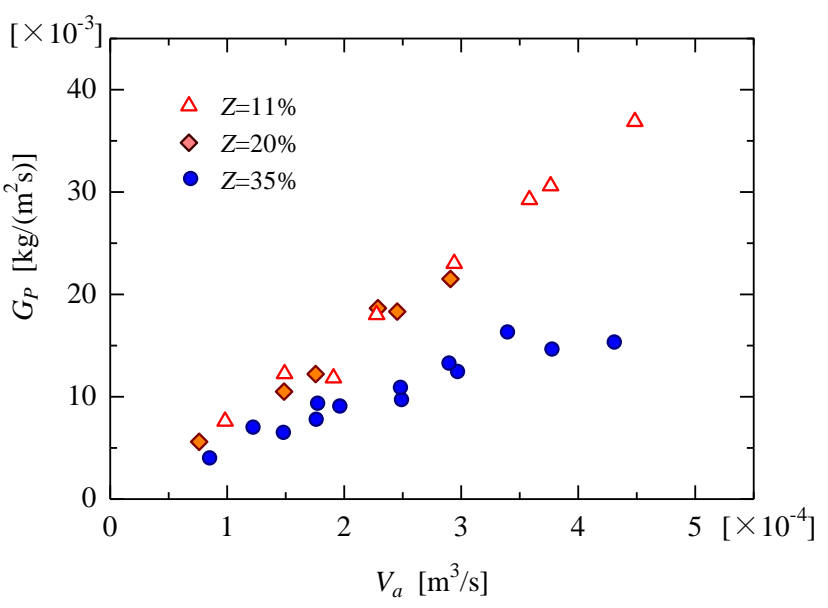

Fig. 5 Relationship between $G_{P}$ and $V_{a}$

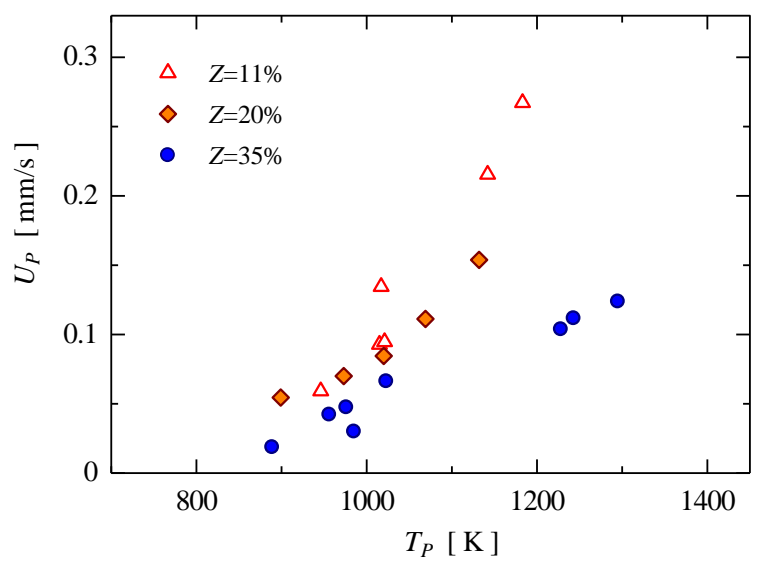

Fig. 7 Relationship between $U_{P}$ and $T_{p}$

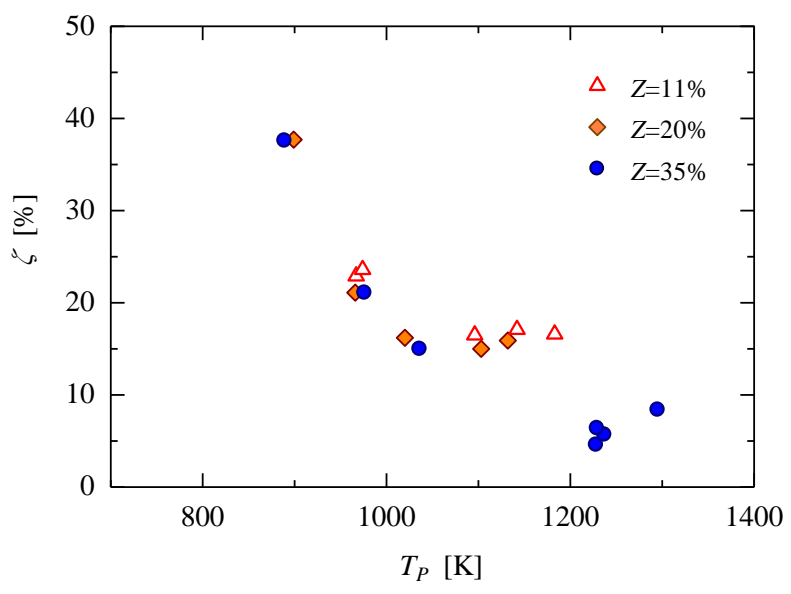

Fig. 8 Relationship between $\zeta$ and $T_{p}$ 


\section{$3 \cdot 3$ 表面燃焼過程の燃焼特性}

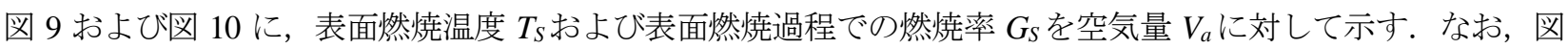
中の含水率 $Z$ の值は，前過程で生成された炭化物の燃料性状の差違を把握する観点から，充填時の木質チップの 含水率を示している.

図 9 より， $T_{S}$ には $Z$ の影響がみられず， $T_{S}$ は $V_{a}$ に依存することがわかる．さらに， $T_{S}$ は $V_{a}$ の増加とともに増 加するが，徐々に増加の割合が小さくなる傾向にあることが確認できる. また，本実験範囲では， $V_{a}$ の調節によ って， $T_{S}$ が約 900〜 $1500 \mathrm{~K}$ の広範囲で変化することがわかる.

図 10 より, $G_{s}$ には $Z$ の差違による影響はみられず $V_{a}$ の増加とともにほぼ線型的に増大し, 空気量による燃焼 率の制御が容易なことがわかる.

さらに，図 9 と図 10 より， $G_{S}$ は $T_{S}$ の上昇とともに増加し，高温域ほど増加の割合（勾配）が大きくなる傾向 にあることを読み取ることができる。この傾向は, 湿り空気中での固体炭素の燃焼実験の結果(辻他, 1981)や, 加熱されたグラファイト表面に空気を吹きつけた場合の実験結果(水谷, 2008)における高温域での $G_{S}$ の勾配が減 少する傾向と矛盾する．この原因として，実験条件の違いによる（本実験では $V_{a}$ により酸化層厚さが変化する） ためと考えられる.

これらの結果から, 分解燃焼によって生成された炭化物は, ほぼ同一の燃料として取り扱うことができる.ま

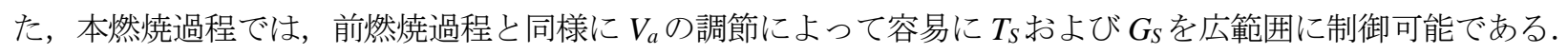

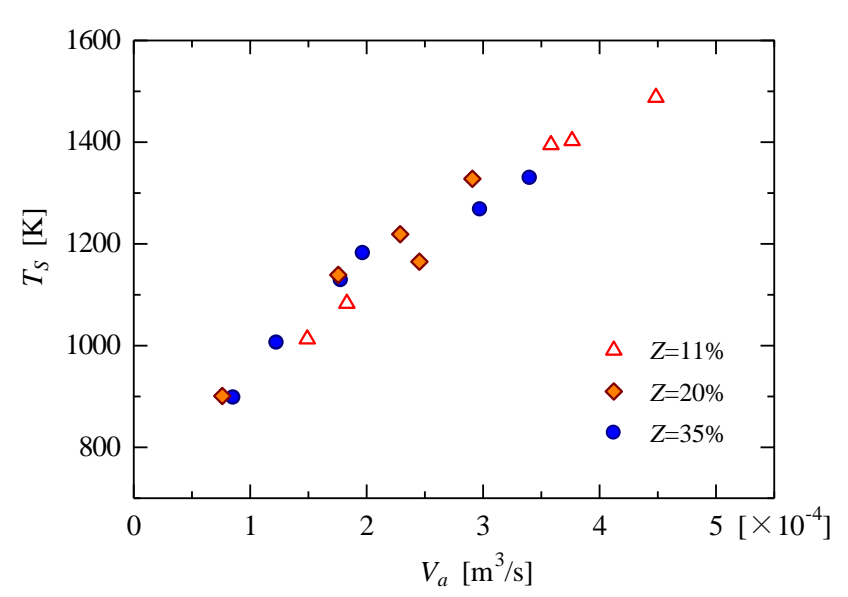

Fig. 9 Relationship between $T_{S}$ and $V_{a}$

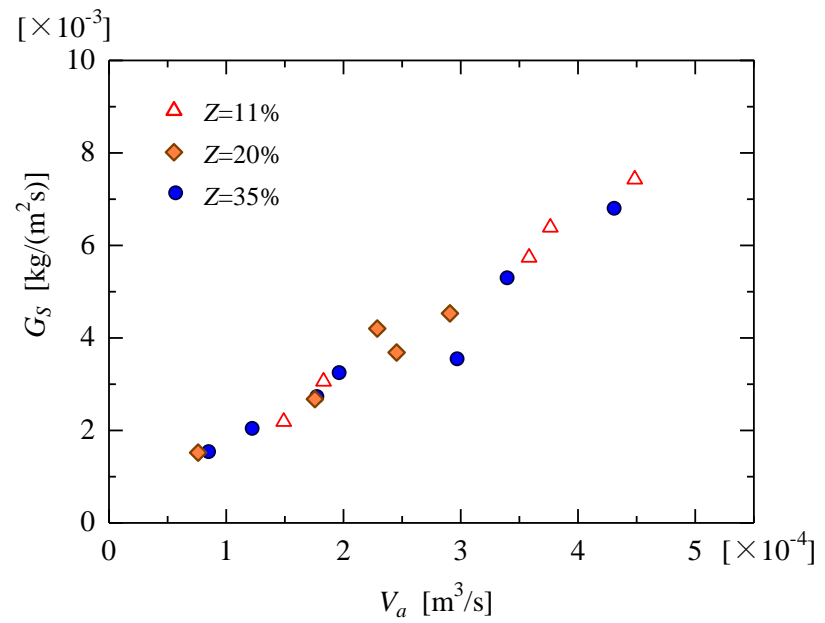

Fig. 10 Relationship between $G_{S}$ and $V_{a}$

\section{$3 \cdot 4$ 燃焼の可視化}

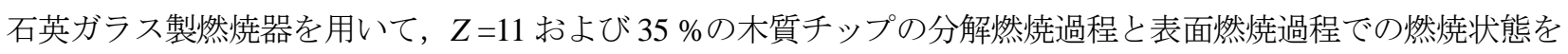
直接観察した結果の一例を燃焼温度とともに図 11 と図 12 にそれぞれ示寸.

図 11 より, 分解燃焼過程では, いずれの含水率においても $T_{P}$ の上昇とともにすなわち空気量の増大とともに, 赤熱部のみの無炎燃焼 $\left(a_{1}, b_{1}\right)$ から火炎の発生 $\left(a_{2}, b_{2}\right)$, 火炎帯の形成・成長 $\left(a_{3}, b_{3}\right)$ 几と燃焼形態が変化す る様子がわかる．さらに図 $11\left(b_{3}\right)$ では，炭化物層が非常に薄く（他の条件（ $\left.a_{1} \sim a_{3}, b_{1}, b_{2}\right)$ では燃焼量の 7 割程度の嵩の炭化物層が観察された), 炭化物層の上方に二次火炎の発生が確認できる.このことから, 図 4 にお ける $Z=35 \%, V_{a}>3 \times 10^{-4} \mathrm{~m}^{3} / \mathrm{s}$ での $T_{P}$ の急激な上昇と高温化は, 前述の炭化物の表面燃燒の影響に, 二次火炎か らの放射伝熱の影響が加わったためと考えられる.

さらに図 12 より, 表面燃焼過程では $T_{S}$ の上昇とともに酸化層厚さが増加寸る様子がわかる. このことより, $T_{S}$ が大きい $\left(V_{a}\right.$ が大きい）領域においても $G_{S}$ が増加するのは, 酸化層厚さが増加したためと考えられる.

燃焼の可視化により, 木質チップの燃焼が, 層状の燃焼部（図 11( $\left.\mathrm{b}_{3}\right)$ 以外の分解燃焼過程では, 酸化層の炭化 物層との界面を可視化では判別できない）を形成し，上部から下方に炭化物を生成しながら進行した後，火格子 
上に酸化層を形成し，燃焼の進行とともに上部の炭化物層が順次沈下して燃焼が維持される様子を確認した。さ らに, $T_{P}$ の上昇とともに分解燃焼過程では無炎燃焼から有炎燃焼へと燃焼形態が変化すること, $T_{S}$ の上昇ととも に表面燃焼過程では酸化層厚さが増加することがわかった。

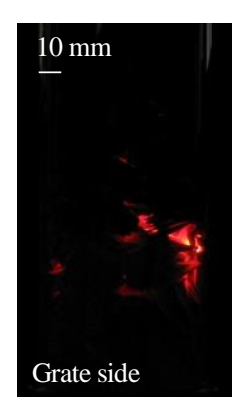

$T_{P}=955 \mathrm{~K}$

$\left(\mathrm{a}_{1}\right)$

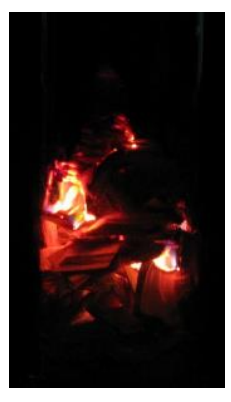

$T_{P}=1015 \mathrm{~K}$

$\left(\mathrm{a}_{2}\right)$

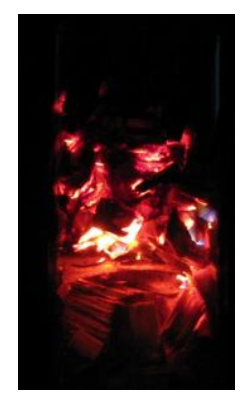

$T_{P}=1270 \mathrm{~K}$

$\left(\mathrm{a}_{3}\right)$

$Z=11 \%\left(\left(\mathrm{a}_{1}\right) \sim\left(\mathrm{a}_{3}\right)\right)$

Fig. 11 Combustion structures in the pyrolytic combustion process

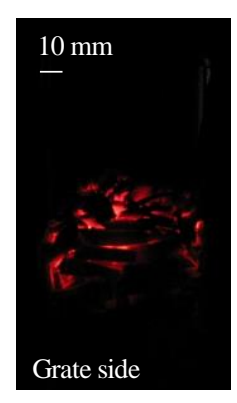

$T_{P}=965 \mathrm{~K}$

$\left(\mathrm{b}_{1}\right)$

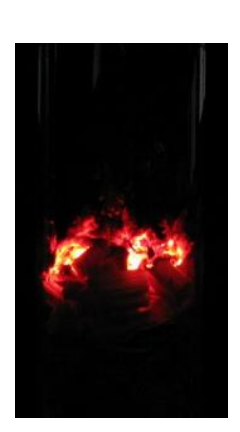

$T_{P}=1005 \mathrm{~K}$

$\left(\mathrm{b}_{2}\right)$ Carbide layer

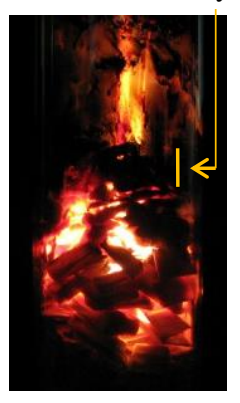

$T_{P}=1235 \mathrm{~K}$

$\left(\mathrm{b}_{3}\right)$

$Z=35 \%\left(\left(b_{1}\right) \sim\left(b_{3}\right)\right)$

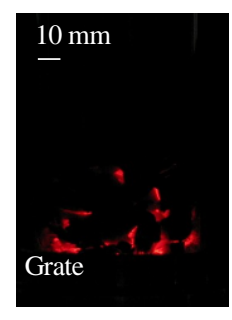

$T_{S}=970 \mathrm{~K}$

$\left(c_{1}\right)$

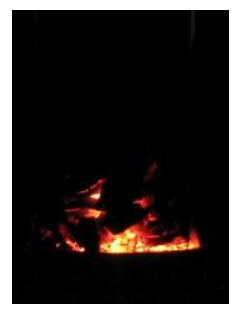

$T_{S}=1065 \mathrm{~K}$

$\left(c_{2}\right)$

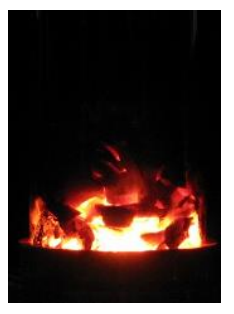

$T_{S}=1255 \mathrm{~K}$

$\left(c_{3}\right)$

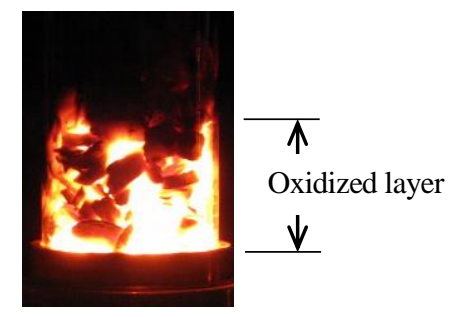

$T_{S}=1405 \mathrm{~K}$

$\left(\mathrm{c}_{4}\right)$

Fig. 12 Combustion structures in the surface combustion process

\section{4. 二段階燃焼法の燃焼メカニズム}

以上の結果から，分解および表面燃焼の二つの燃焼過程を有する二段階燃焼法を提案し，その火層構造の概念 図を図 13 に示寸.

分解燃焼過程では，図 13(a)のように層状の酸化層が形成され，上部から下方に進行する. 酸化層の下方には酸 化層からの熱伝導と放射による熱供給によって乾留層が形成され，さらにその下方には酸化層の影響を受けない 燃料層が存在する．また，酸化層の上方には，分解燃焼により生成された炭化物層があり，その中を高温の燃焼 ガスが通過する.

一方, 表面燃焼過程では, 図 13(b)のように火格子上に酸化層が形成され, 酸化層の上方に炭化物層が存在する. そして燃焼後の灰分は火格子を通って下方に落下寸る. なお，燃焼の進行とともに上部の炭化物層が重力により 沈下して酸化層は定常的に保持される.

この二段階の燃焼プロセスは，以下の手法とメカニズムによって実現できると考えられる.

(1) 縦型の火格子燃焼器を使用する.

（2）木質バイオマス燃料はチップ化して用いる. チップ化によって燃料個々の熱容量が小さくなり，温度応答 性が向上して層状の酸化層を形成できる.

（3）燃料はバッチ方式で用いる．このことで，酸化層の移動が可能となる.

（4）燃焼用空気は, 燃焼器下方から供給する. 一方, 木質チップの燃焼は, 燃料層の上部から空気の流れに対 向させて行う。このことにより, 酸化層が上部から下方へ進行する.さらに，乾留層の形成を酸化層から 
の熱伝導と放射伝熱のみで行うことで，燃焼による発熱量を効率的に酸化層維持に利用でき，乾留層形成 のための伝熱量の一部を燃焼用空気の予熱にも活用できる.

（5） 供給空気量は少なくし，空気比が $0.3 \sim 0.5$ 程度とする. この低空気比燃焼によって熱分解支配の燃焼が可 能となり，生成された炭化物を自己消火させて分解燃焼と表面燃焼とが分離できる．燃焼の分離によって 燃焼の制御が容易になり，低温燃焼も可能となる.

（6）酸化層の進行とともに，酸化層の後方に炭化物層が形成され，その中を高温の燃焼ガスが通過する.

（7）酸化層が火格子上に到達して分解燃焼が終了寸ると，火格子上では炭化物の燃焼による酸化層が形成され る.

（8）燃焼後の灰分は火格子の隙間を通って下方に落下し, 燃焼分は炭化物（層）が重力によって沈下して酸化 層を保持する.

（9）（8）を繰り返し，蓄積した最後の炭化物まで燃焼が持続する.

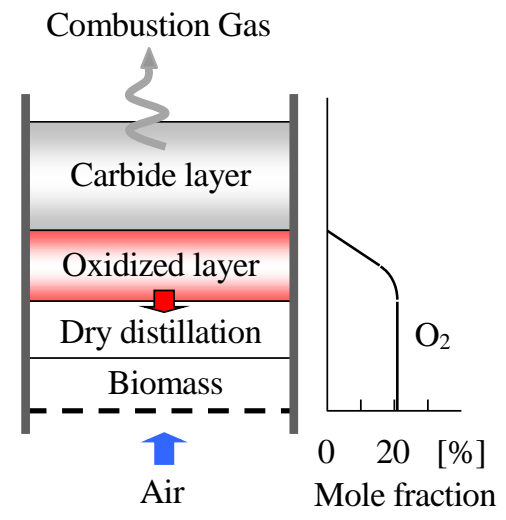

(a) Pyrolytic combustion process
Combustion Gas

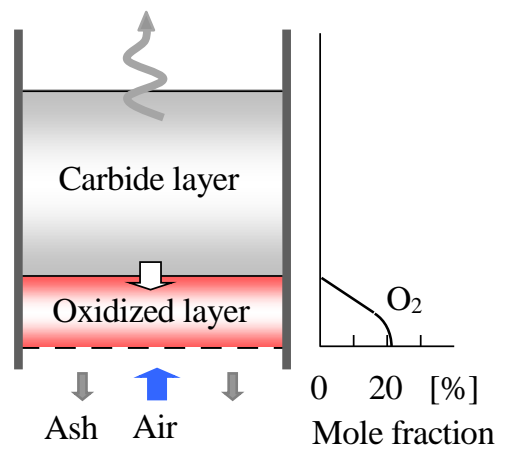

(b) Surface combustion process

Fig.13 Fire layer of two-stage combustion method

\section{5. 結 言}

本報では，木質バイオマスの燃焼温度や燃焼率を簡便に広範囲で制御できる二段階燃焼法を提案し，その基礎 燃焼特性と燃焼のメカニズムについて検討した，その結果，以下の知見を得た。

（1） 本燃焼法では，木質チップの燃焼を分解燃焼過程と表面燃焼過程とに分離して，なおかつ燃焼を連続して 二段階で行うことを確認した.

（2）空気量の調節により, 分解燃焼過程では約 $900<T_{P}<1300 \mathrm{~K}$, 約 $5 \times 10^{-3}<G_{P}<37 \times 10^{-3} \mathrm{Kg} /\left(\mathrm{m}^{2} \cdot \mathrm{s}\right)$, 表面 燃焼過程では約 $900<T_{S}<1500 \mathrm{~K}, 1.5 \times 10^{-3}<G_{S}<7.5 \times 10^{-3} \mathrm{Kg} /\left(\mathrm{m}^{2} \cdot \mathrm{s}\right)$ で然焼温度および然焼率が制御可能 であることがわかった。

（3）分解燃焼過程における炭化物生成プロセスは，木質バイオマスの一般的な炭化とほぼ同様であることがわ

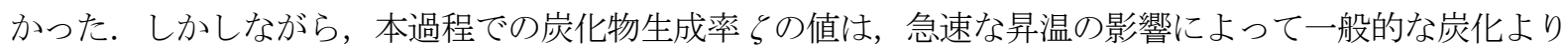
も減少する.

（4）燃焼の可視化により，木質チップが分解および表面燃焼過程の二段階で燃焼することを確認した．また， 分解燃焼過程では酸化層が層状で進行し， $T_{P}$ の上昇（ $V_{a}$ の増加）につれて無炎燃焼から有炎燃焼一燃焼形 態が変化すること, 酸化層の進行とともにその後方に炭化物が生成・蓄積されていく様子を確認できた. 表面燃焼過程では， $T_{S}$ の上昇（ $V_{a}$ の増加）につれて酸化層の厚さが増加することがわかった.

\section{謝 辞}

終わりに, 本研究の実験を行うにあたり, 愛媛大学学部生・小笠原輝君および森山純君にご協力いただいた. ここに記し，謝意を表す。 


\section{文献}

福山伍郎，里中聖一，木材炭化温度と生成物，北海道大学農学部演習林研究報告(1954), pp.127-149.

日本木質ペレット協会，木質ペレット品質規格(2011), pp.5-7.

右田伸彦，米沢保正，近藤民雄 編，木材科学（上） (1968), p.65.

右田伸彦，米沢保正，近藤民雄 編，木材科学（下） (1968), p.91.

水谷幸夫，燃焼工学(2008), pp.173-175.

永橋優純，村上和彦，雑賀高，木質系バイオ燃料の利用形態と燃焼特性一研究・開発動向一，日本燃焼学会誌，

Vol.51, No.158 (2009), ,pp.310-317.

新エネルギー・産業技術総合開発機構，NEDO 再生可能エネルギー技術白書 PDF 版(2014).

農林省林業試験場編，木材工業ハンドブック(1973), p.912.

日本エネルギー学会編, バイオマスハンドブック(2009), pp.88-94, pp.108-109.

日本機械学会編, 燃焼工学ハンドブック(2002), p.177.

日本機械学会編，伝熱工学資料（第 5 版）(2009), p.289.

辻廣, 松井潔, 牧野敦, 湿り空気中での固体炭素の燃焼, 東京大学宇宙航空研究所報告, Vol. 17, No. 1(B) (1981), pp.241-259.

\section{References}

Fukuyama, G. and Satonaka, S., Wood carbonization temperature and the products, Reserch bulletines of the college experiment forests Hokkaido university (1954), pp.127-149 (in Japanese).

Japan Wood Pellet Association, Quality Standard of Wood Pellet (2011), pp.5-7 (in Japanese).

Migita, N., Yonezawa,Y. and Kondo,T. ed., Mokuzai Kagaku, the first volume (1968), p.65, Kyoritsu Shuppan Co.,Ltd. (in Japanese)

Migita, N., Yonezawa,Y. and Kondo,T. ed., Mokuzai Kagaku, the second volume (1968), p.91, Kyoritsu Shuppan Co.,Ltd. (in Japanese).

Mizutani, Y., Nensyo Kougaku (3rd) (2008), pp.173-175, Morikita Publishing Co., Ltd. (in Japanese).

Nagahashi, Y., Murakami, K. and Saika, T., Utilization and combustion characteristics of woody bio-fuel-trend of the research and development, Journal of the Combustion Society of Japan Vol.51, No.158 (2009), pp.310-317 (in Japanese).

New Energy and Industrial Technology Development Organization, NEDO White Paper on Renewable Energy (2014) (in Japanese).

The Government Forest Experiment Station, Mokuzai-Kogyo Handbook (Hand book of Wood Industry) (1973), p.912 (in Japanese).

The Japan Institute of Energy ed., Biomass Handbook (2009), pp.88-94, pp.108-109 (in Japanese).

The Japan Society of Mechanical Engineers ed., JSME Combustion Handbook (2002), p.177, The Japan Society of Mechanical Engineers (in Japanese).

The Japan Society of Mechanical Engineers ed., JSME Data Handbook: Heat Transfer (2009), p.289, The Japan Society of Mechanical Engineers (in Japanese).

Tsuji, H., Matsui, K. and Makino, A., Combustion of solid carbon under humid air flows, Vol.17, No.1(B) (1981), pp.241-259, Report of Institute of Space and Aeronautical Science, University of Tokyo (in Japanese). 